\title{
APLIKASI TELEGRAM (TELE-EDUKASI) DALAM PEMBELAJARAN IPA DI MADRASAH IBTIDAIYAH
}

Sholikah, email : sholikah@stitmatuban.ac.id

Nur Ijazatin Septia

\begin{abstract}
Formal education becomes an important role as a forum to develop a lot of learning, be it learning about attitudes or about subjects. One of which the writer will discuss is on Natural Sciences (IPA). Science subjects at the elementary school level are the child's initial process of getting to know the environment in the scope of formal education. Science subjects are important to be introduced to children so that children are able to know what is in their environment. Especially about the life of living things around him. So it takes innovation in the learning process.

Telegram is a cloud-based, multi-platform instant messaging service application that is free and non-profit. Telegram Client is available for mobile phone devices (Android, iOS, Windows Phone, Ubuntu Touch) and computer peripheral systems (Windows, OS X, Linux). Users can send messages and exchange photos, videos, stickers, audio, and all types of files or files.

The implementation of learning using the telegram application (tele-education) to practice working on science problems shows a gradual increase, namely experiencing an increase in positive things and a decrease in negative things according to the student questionnaire contained in the appendix. Means it can be concluded that the implementation went better and smoothly in each cycle.
\end{abstract}

Keywords: Application, Telegram, Natural Science Learning, Madrasah Ibtidaiyah 


\section{A. Latar Belakang}

Pendidikan formal menjadi penting peranannya sebagai wadah untuk mengembangkan banyak pembelajaran, baik itu pembelajaran tentang sikap ataupun tentang mata pelajaran. Salah satunya yang akan penulis bahas ialah pada mata pelajaran Ilmu Pengetahuan Alam (IPA). Pembelajaran tersebut menjadikan anak dapat mengetahui tentang lingkungannya untuk kemudian dapat diaplikasikan di kehidupan yang sebenarnya. Namun, dalam era global yang semakin menuntut pembelajaran menggunakan media berbasis teknologi ini, banyak sekali keterbatasan yang menjadi hambatan bagi seorang pendidik untuk mengembangkan metode pembelajarannya. Keterbatasan tersebut berupa keterbatasan dalam hal media, kurangnya kemampuan guru untuk mengembangkan metodenya, serta kebijakan kurikulum mengenai alokasi waktu pembelajaran yang dirasa belum cukup untuk guru bisa menerapkan metode pembelajarannya secara efektif sehingga dapat mencapai target pembelajaran sesuai dengan ketentuan.

Mata pelajaran IPA di tingkat sekolah dasar merupakan proses awal anak untuk mengenal lingkungan pada lingkup pendidikan formal. Mata pelajaran IPA penting untuk dikenalkan pada anak agar anak mampu mengenal apa saja yang ada di lingkungannya. Terutama tentang kehidupan makhluk hidup di sekitarnya. Sehingga dibutuhkan inovasi dalam proses pembelajarannya.

Teknologi pendidikan bisa diterapkan pada salah satu sisi pendidikan yakni dalam proses pembelajaran. Teknologi pembalajaran inilah yang nantinya akan secara langsung membantu dalam memecahkan masalah belajar yang sering menjadi masalah utama bagi seorang pelajar. Usaha yang dapat dilakukan untuk dapat menerapkan teknologi dalam suatu pembelajaran bukanlah sesuatu yang mudah bagi lembaga pendidikan yang bernaung dalam suatu yayasan. Faktor dana yang terbatas biasanya menjadi pemicu utama pada tingkat kelengkapan sarana maupun fasilitas yang menunjang bagi siswa ataupun pendidik untuk menerapkan teknologi dalam proses belajar mengajar. Hal inilah yang seringkali menghambat seorang pendidik untuk berinovasi pada pembelajarannya. Namun, pada era ini, ada wujud dari teknologi yang telah menjangkau hampir seluruh lapisan masyarakat. Teknologi tersebut berupa perangkat mobile seperti smartphone, tablet yang mempunyai sistem operasi berbasis android. 
Penggunaan smartphone berbasis android sampai saat ini memang masih dilarang di lingkungan sekolah Madrasah Ibtidaiyah (MI). Karena dikhawatirkan dapat mengganggu pembelajaran yang terjadi di sekolah. Namun, pendidik dapat menggunakan teknologi ini sebagai alat untuk belajar diluar jam sekolah maupun di jam sekolah dengan seijin guru. Teknologi android yang digunakan dalam pembelajaran ini memanfaatkan aplikasi telegram yang telah dirancang secara khusus untuk bisa di isi soal-soal yang berhubungan dengan materi yang sebelumnya diajarkan di sekolah dan untuk selanjutnya soal tersebut bisa dikerjakan di rumah ataupun di sekolah oleh siswa. Melalui pembelajaran menggunakan android diharapkan siswa tertarik untuk terus mengerjakan soal karena memanfaatkan aplikasi yang ada dalam android dan hanya bisa diakses sesuai waktu yang telah ditentukan oleh pendidik.

Khusus bagi siswa sekolah dasar, aplikasi tele-edukasi ini diharapkan dapat digunakan untuk pembelajaran sekaligus sebagai wadah untuk latihan mengerjakan soal IPA yang juga memuat materi di kelas sebelumnya. Selain itu, dengan pembelajaran menggunakan android tersebut, diharapkan siswa lebih terlatih dalam mengerjakan dan menjawab soal serta dapat mengingat lebih lama materi yang terdapat pada soal dan dapat mencapai target sesusai dengan kriteria ketuntasan minimum yang telah ditetapkan oleh lembaga.

\section{B. Aplikasi Telegram (Tele-Edukasi) dalam Pembelajaran IPA di Madarasah Ibtidaiyah}

Pesatnya kemajuan zaman yang diikuti dengan pesatnya juga kemajuan dalam bidang pendidikan, sangat diperlukan pembaharuan dalam hal teknologi pendidikan sebagai penunjang proses pembelajaran sekaligus sebagai bentuk inovasi dalam proses belajar mengajar. Menurut (Abdulhak dan Darmawan, 2015: 107) teknologi sebagai proses, maka pendidikan dapat dikatakan sebagai salah satu teknologi, karena pendidikan itu merupakan proses untuk menjadikan manusia terdidik, atau proses untuk memperoleh nilai tambah (added value), sehingga dapat dikatakan education as technology.

Teknologi pendidikan mempunyai fungsi-fungsi yang meliputi: Sumber Belajar, Pengelolaan Pendidikan dan Pengembangan Pendidikan. Dari fungsi-fungsi tersebut Menurut (Abdulhak dan Darmawan, 2015: 110) Teknologi pendidikan sendiri merupakanbidang yang mencakup penerapan proses yang kompleks dan terpadu dalam menganalisis dan memecahkan masalah-masalah belajar manusia. Teknologi Pendidikan juga merupakanprofesi 
dalam bentuk usaha yang terorganisir untuk menetapkan teori, teknik intelektual, dan penerapan praktis teknologi pendidikan.

Selain itu, Barbara Seels (dalam Abdulhak dan Darmawan, 2015: 110) perkembangan terakhir, teknologi pendidikan secara konseptual didefinisikan sebagai: teori dan praktik dalam desain, pengembangan, pemanfaatan, pengelolaan, penilaian dan penelitian proses, sumber dan sistem untuk belajar. Definisi tersebut mengandung pengertian ada empat komponen dalam teknologi pembelajaran yaitu: (a) teori dan praktik; (b) desain, penggembangan, pemanfaatan, pengelolaan, penilaian dan penelitian; (c) proses, sumber dan sistem; (d) untuk belajar (Abdulhak dan Darmawan, 2015: 110).

Pada tahapan teknologi yang sederhana digunakan papan tulis, bagan, objek nyata dan model-model yang sederhana. Pada tahapan teknologi menengah digunakan OHP, slide, film proyeksi, peralatan elektronik yang sederhna untuk pengajaran dan peralatan proyeksi (LCD). Sedangkan tahapan teknologi yang tinggi berkaitan dengan penggunaan paket-paket yang kompleks seperti belajar jarak jauh dengan menggunakan radio, televisi, modul, computer assisted instruction, serta pengajaran atau simulasi yang kompleks, dan sistem informasi dial access melalui telepon dan lain sebagainya (Abdulhak dan Darmawan, 2015: 107).

Usaha untuk mengembangkan sistem pendidikan yang sudah ada (tradisional) secara tatap muka, sekarang ini telah banyak digunakan sistem pendidikan yang tidak dibatasi oleh ruang dan waktu sejalan dengan berkembangnya teknologi informasi. Teknologi tersebut memanfaatkan dunia maya sebagai wadah untuk menjalankan sistem pendidikan, pendidikan dengan memanfatkaan teknologi informasi inilah yang dikenal dengan e-learning. Menurut (Munir, 2008: 202) Huruf e pada e-learning berarti elektronik yang kerap disepadankan dengan kata virtual (maya) atau distaance (jarak). Dari hal ini kemudiaan muncul istilah virtual learning (pembelajaran di dunia maya) atau distance learning (pembelajaran jarak jauh). Sedangkan kata learning sering diartikan dengaan belajar pendidikan (education) atau pelatihan (training). Jadi e-learning berarti pembelajaran dengan menggunakan media atau jasa bantuan peralaatan elektronika. Dalam pelaksanaannya, e-learning menggunakan jasa audio, video, perangkat computer, atau kombinasi dari ketiganya.

E-learning memungkinkan proses pembelajaran melalui media dan teknologi informasi berupa komputer dan jaringan internet atau intranet. Dari hal tersebut bermakna, bahwa $e$ learning adalah proses learning (pembelajaran) menggunakan/memanfaatkan TIK sebagai 
tools. Fokus e-learning adalah pada "learning"(belajar) dan bukan "e" (electronic)(Munir, 2008: 203). Selain itu, menurut Effendi dan Bob Soelaeman (dalam Munir, 2008: 203) E-

Learning juga berupa proses transformasi pembelajaran dari "Instructur Centric" ke "Learner Centric".

Pada pembelajaran e-learning pengajar cukup mengupload bahan-bahan ajar termasuk sol-soal evaluasi pada situs e-learning dan peserta didik dapat mempelajarinya dengan membuka situs tersebut dimanapun dan kapanpun. Dengan begitu, teknologi dapat bermanfaat secara positif sebagai alat pembelajaran yang membantu interaksi antara pengajar dan peserta didik. Dalam pembelajaran yang memanfaatkan e-learning pengajar dan peserta didik tidak bertindak sebagai objek saja melainkan menjadi subjek yang menjalankan $e$-learning tersebut. (Munir, 2008: 203) menyebutkan E-Learning merupakan aplikasi TIK yng bersifat pragmatis yang memerlukan dukungan insfrastruktur dan superstruktur lain yang terkait dengan lembaga pendidikan dan pengajar maupun peserta didik. Oleh karena itu, keberhasilan penggunaan $e$ learning dipengaruhi juga oleh daya beli pengajar dan peserta didik terhadap fasilitas TIK yang dibutuhkan untuk engakses internet, dengan menyediakan computer, modem, laptop, note book, smartphone dan lain-lain.

Menurut Munir (2008: 205) mengemukakan bahwa e-learning mempunyai beberapa kelebihan sebagai berikut:

1. Memberikan pengalaman yang menarik bagi peserta didik, karena kemampuaannya daapat berinteraksi langsung, sehinga pemahaman terhadap materi pelajaran akan lebih bermakna (meaningfull) , mudah dilihat, mudah iingat dan mudah pula untuk diungkapkan kembali.

2. Dapat memperbaikitingkat pemahaman dan daya ingat seseorang (Retention of Information) terhadap knowledge yang disampaikan, karena konten yang bervariasi, interaksi yang menarik perhatian, immadiete feedback dan adanya interaksi dengan $e$ learner dan e-instructure lain.

3. Adanya kerja sama dengan komunitas on-line sehingga memudahkannya proses transfer informasi dan komunikasi, sehingga setiap elemen tidak akan kekurangan sumber /bahan beljar.

4. Administrasi dan pengurusan yang terpusat, sehingga memudahkaan dilakukannya akses dalam operasionalnya. 
5. Menghemat atau mengurangi biaya pendidikan, seperti berkuraangnya biaya untuk membayar pengajar atau biaya akomodasi dan transportasi peserta didik ke tempat belajar.

6. Pembelajaran dengan dukungan teknologi internet membuat pusaat perhatian dalam pembelajaran tertuju pada peserta didik, sebgaiana ciri pokok dari e-leaning. Ini berarti dalam pembeljaran peserta didik tidak bergantung sepenuhnya kepada pengajar. Peserta didik belajar dengan mandiiri untuk menggali (mengeksplorasi) ilmu pengetahuan melalui internet dan media teknologi informasi lainnya.

Selain itu, Bates dan Wulf (Munir, 2008: 205) mempunyai pendapat bahawa e-learning memiliki kelebihan sebagai berikut:

1. Meningkatkan interaksi pembelajaran (enhance interactivity)

2. Memermudah interaksi pembelajaran daari mana dan kapan saja (time and place flexibility)

3. Memiliki jangkauan yang lebih luas (potantial to reach a global audience)

4. Memperudah penyempurnaan dan penyimpanan materi pembelajaran (easy updating of content as well as archivable capabilities).

Sedangkan kekurangan e-learning yang diuraikan oleh Nursalam (2008:140) sebagai berikut :

1. Kurangnya interaksi antara pengajar dan pelajar atau bahkan antar pelajar itu sendiri.

2. Kecenderungan mengabaikan aspek akademik atau aspek sosial dan sebaliknya membuat tumbuhnya aspek bisnis/komersial.

3. Proses belajar mengajar cenderung ke arah pelatihan daripada pendidikan.

4. Berubahnya peran pengajar dari yang semula menguasai teknik pembelajaran konvensional, kini juga dituntut mengetahui teknik pembelajaran yang menggunakan ICT (information, communication, dan technology).

5. Tidak semua tempat tersedia fasilitas internet ( mungkin hal ini berkaitan dengan masalah tersedianya listrik, telepon, ataupun komputer).

6. Kurangnya sumber daya manusia yang menguasai internet.

7. Kurangnya penguasaan bahasa komputer.

8. Akses pada komputer yang memadai dapat menjadi masalah tersendiri bagi peserta didik. 
9. Peserta didik bisa frustasi jika mereka tidak bisa mengakses grafik, gambar, dan video karena peralatan yang tidak memadai.

10. Tersedianya infrastruktur yang bisa dipenuhi.

11. Informasi dapat bervariasi dalam kualitas dan akurasi sehingga penduan dan fitur pertanyaan diperlukan.

12. Peserta didik dapat merasa terisolasi.

Telegram adalah sebuah aplikasi layanan pengirim pesan instan multiplatform berbasis awan yang bersifat gratis dan nirlaba. Klien Telegram tersedia untuk perangkat telepon seluler (Android, iOS, Windows Phone, Ubuntu Touch) dan sistem perangkat komputer (Windows, OS X, Linux). Para pengguna dapat mengirim pesan dan bertukar foto, video, stiker, audio, dan semua tipe fail atau berkas (https://id.wikipedia.org/wiki/Telegram_\%28aplikasi\%29).

Pada (https://www.centerklik.com/apa-aplikasi-telegram-cara-menggunakan-telegram/) telegram adalah Aplikasi pesan chatting yang memungkinkan pengguna untuk mengirimkan pesan chatting rahasia yang dienkripsi end-to-end sebagai keamanan tambahan. Dengan Telegram Anda juga dapat berbagi lebih dari sekedar gambar dan video, tapi Telegram juga memungkinkan Anda mentransfer dokumen atau mengirim lokasi Anda saat ini ke teman dengan mudah.

Aplikasi telegram dapat digunakan sebagai wadah untuk belajar soal-soal pada semua mata pelajaran termasuk IPA. Dalam hal ini penulis meneliti sebuah program yang telah dimasukkan dalam telegram dan dapat digunkan untuk belajar dimanpun dan kapanpun, program tersebut diberi nama tele-edukasi. Tele-edukasi berisi soal-soal IPA kelas VI dan digunakan sebagai tugas untuk dapat dibuka dan dikerjakan siswa kelas VI di MI. Program ini dibawah kendali guru sehingga siswa tetap terkontrol dalam penggunaannya.

Namun, sama halnya dengan hal-hal lain yang bersangkutan dengan pembelajaran, aplikasi ini juga memiliki kelebihan ataupun kelemahan jika digunakan dalam pembelajaran siswa MI. Adapun kekurangan dari aplikasi ini diantaranya: 1). Membutuhkan kuota internet ketika melaksanakan pembelajaran. 2). Karena berupa alat elektronik, untuk ukuran siswa MI banyak yang belum memiliki HP berbasis android atau laptop secara pribadi, dalam artian penggunaannya masih belum bisa bebas. 3). Penggunaannya tergantung pada sinyal, jika sinyal tiba-tiba hilang maka pembelajaranpun akan secara otomatis berhenti. Untuk kelebihan aplikasi ini jika digunakan sebagai media pembelajaran, diantaranya: 1). Memudahkan siswa 
untuk mengingat materi yang ada pada soal, karena setiap siswa selesai menjawab akan langsung muncul keterangan jawaban tersebut benar atau salah. 2). Siswa akan lebih bersemangat karena alat yang digunakan dalam pembelajaran termasuk dalam teknologi. 3). Siswa bisa mengerjakan soal-soal latihan tersebut dimanapun selagi sistemnya diaktifkan oleh guru.4) Menghemat pemakaian kertas ujian.

\section{Metode Penelitian}

Jenis penelitian yang digunakan Penelitian Tindakan Kelas (PTK).Penelitian tindakan kelas dapat diartikan sebagai penelitian yang berorientasi pada penerapan tindakan dengan tujuan peningkatan mutu atau pemecahan masalah pada sekelompok subyek yang diteliti dan mengamati tingkat keberhasilan atau akibat tindakannya, untuk kemudian diberikan tindakan lanjutan yang bersifat penyempurnaan tindakan atau penyesuaian dengan kondisi dan situasi sehingga diperoleh hasil yang lebih baik (Trianto, 2012:13). Sedangkan menurut (Arikunto, 2014: 3) penelitian tindakan kelas merupakan suatu pencermatan terhadap kegiatan belajar berupa tindakan, yang sengaja dimunculkan dan terjadi di dalam kelas secara bersama.

Tujuan dari penelitian tindakan kelas ini adalah peningkatan atau perbaikan terhadap kinerja belajar siswa di sekolah, peningkatan terhadap mutu proses pembelajaran di kelas, peningkatan terhadap kualitas prosedur dan alat evaluasi yang digunakan untuk mengukur proses dan hasil belajar siswa, peningkatan terhadap masalah-masalah pendidikan di sekolah, serta peningkatan dan perbaikan terhadap kualitas penerapan kurikulum dan pengembangan kompetensi siswa di sekolah.

Dalam Penelitian tindakan kelas ini menggunakan model yang dikembangkan oleh (Arikunto dkk., 2015 : 41 - 43). yang terdiri dari 4 tahapan yaitu: a) Perencanaan (planning)., b) Pelaksanaan tindakan (action)., c) Pengamatan (observing)., dan d) Refleksi (reflection).

Penelitian tindakan kelas pada setiap siklus akan dilakukan dengan tahapan sebagai berikut: 

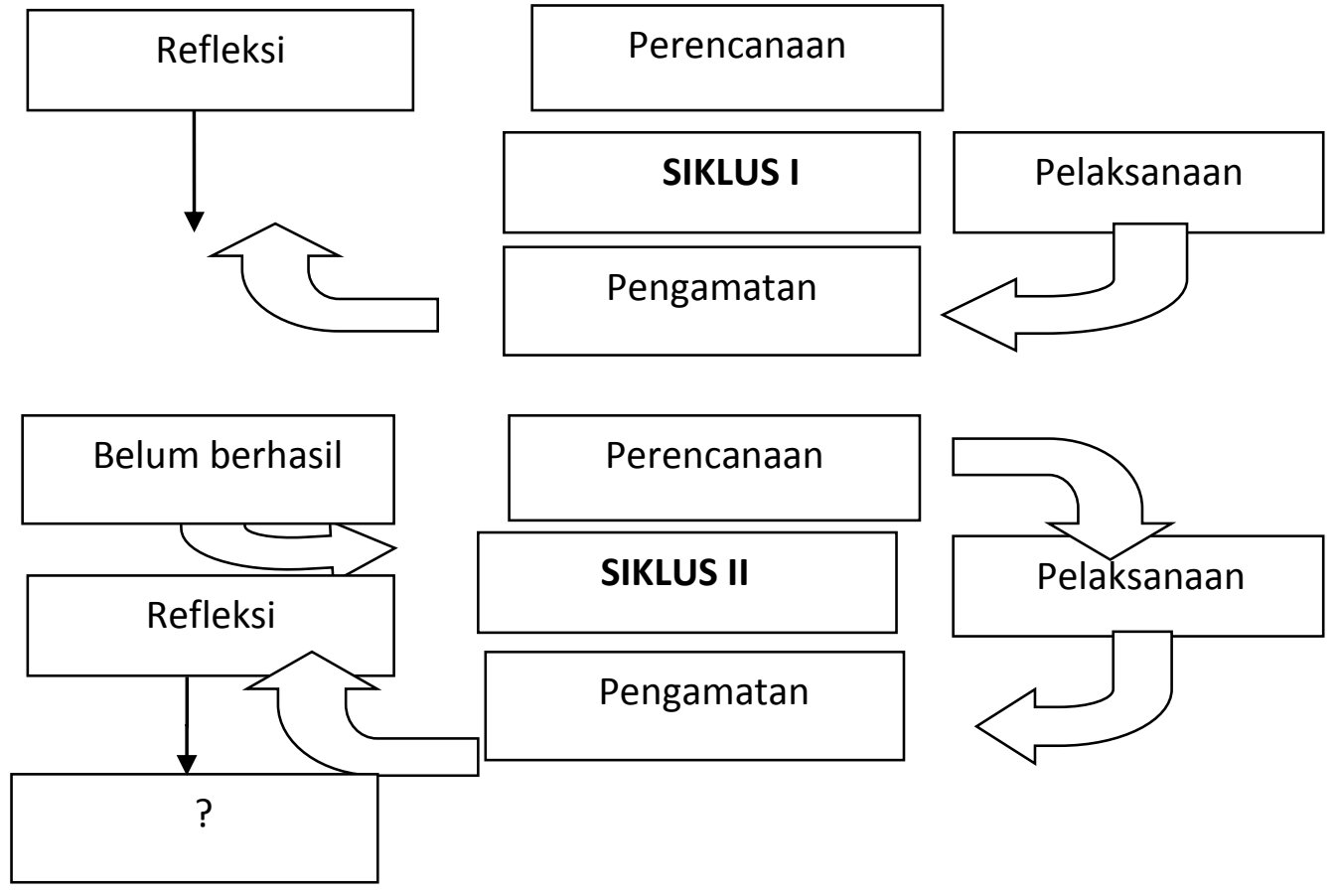

\section{Gambar 3.1 Model PTK(Arikunto dkk., 2015 : 41-43)}

Penjelasan alur PTK dalam tiap siklusnya adalah sebagai berikut.

\section{Perencanaan tindakan (Planning)}

Dalam tahap pertama ini guru menjelaskan tentang apa, mengapa, kapan, di mana, oleh siapa, dan bagaimana tindakan tersebut dilakukan. Dalam tahap menyusun rancangan iniguru menentukan titik atau fokus peristiwa yang perlu mendapatkan perhatian khusus untuk diamati, kemudian membuat sebuah instrumen pengamatan untuk membantu peneliti merekam fakta yang terjadi selama tindakan berlangsung.

2. Pelaksanaan Tindakan (Acting)

Tahap kedua dari penelitian tindakan adalah pelaksanaan yang merupakan implementasi atau penerapan isi rancangan, yaitu menggunakan tindakan di kelas. yang perlu diingat dalam tahap kedua ini peneliti harus ingat dan berusaha mentaati apa yang sudah dirumuskan dalam rancangan.

3. Pengamatan (Observing)

Tahap ketiga yaitu kegiatan pengamatan yang dilakukan oleh peneliti.

\section{Refleksi (Reflecting)}

Tahap keempat merupakan kegiatan untuk mengemukakan kembali apa yang sudah dilakukan. Pada tahap ini dimaksudkan untuk mengkaji secara menyeluruh tindakan yang 
telah dilakukan, berdasarkan data yang telah terkumpul, dan kemudian melakukan evaluasi guna menyempurnakan tindakan yang berikutnya.

\section{Pelaksanaan Latihan Soal Melalui Aplikasi Telegram}

Penggunaan aplikasi telegram untuk mengerjakan latihan soal IPA berjalan dengan lancar dan menyenangkan. Siswa merasa bersemangat dan antusias ketika guru mulai memberi penjelasan tentang aplikasi telegram (tele-edukasi) sampai guru memberikan contoh cara menggunakan aplikasi ini untuk mengerjakan soal IPA. Hal ini dibuktikan dengan hasil angket siswa yang mengalami peningkatan pada pertanyaan yang bersifat positif yakni untuk aspek no. 1, 3 dan 5 .

Pada aspek no.1 dari 63,15\% menjadi 89,47\%, aspek no.3 dari 52,63\% menjadi 63,15\% dan pada aspek no.5 dari 42,10\% meningkat menjadi 57,89\%. Sedangkan mengalami penurunan untuk pertanyaan yang bersifat negatif yakni pada aspek no.2,4,6,7 dan 8 pada siklus I dan siklus II. Pada aspek no.2 dari 36,84\% menjadi 5,26\% aspek no.4 dari 47,36\% menjadi 31,57\%, aspek no.6 dari 47,36 menjadi 26,31, aspek no.7 dari 42,10\% menjadi $31,57 \%$ dan aspek no. 8 dari $63,15 \%$ menurun menjadi $10,52 \%$.

Berdasarkan hasil perkembangan tersebut, peneliti merasa pelaksanaan penggunaan aplikasi telegram (tele-edukasi) dalam pengerjaan latihan soal IPA telah berjalan dengan baik dan lancar tanpa banyak hambatan.

Penggunakan aplikasi telegram untuk mengerjakan latihan soal IPA memiliki dampak positif dalam meningkatkan prestasi belajar siswa. Hal ini dapat dilihat dari semakin meningkatnya hasil belajar siswa pada mata pelajaran IPA. Ketuntasan klasikal meningkat pada tiap tahapnya yaitu $21,05 \%$ sebelum siklus dilaksanakan menjadi $84,21 \%$ pada siklus I dan terus meningkat menjadi 94,73\% di siklus II. Sehingga dapat disimpulkan bahwa pada setip siklus mengalami peningkatan pada ketuntasan belajar siswa secara klasikal.

Berdasarkan analisis data observasi siswa, semangat, aktifitas, dan keberanian serta kepercayaan diri anak mengalami peningkatan. Hal ini disebabkan oleh kemampuan guru dalam mengelola kelas yang akhirnya berdampak positif terhadap prestasi belajar siswa yang dapat ditunjukkan dengan meningkatnya nilai rata-rata siswa dari siklus I ke siklus II. Hasil rekapitulasi angket juga menunjukkan tingkat ketertarikan serta kemampuan sisa dalam mengoperasikan aplikasi telegram. 
Kondisi kelas terkendali dan berjalan dengan lancar sesuai dengan rencana yang dirumuskan dalam RPP. Selama observasi guru telah melakukan setiap tahap-tahap dalam penggunan aplikasi telegram, hal ini menunjukkan kemampuan guru dalam mengelola kelas.

Selain itu, berdasarkan analisis data, diperoleh aktifitas siswa dalam proses latihan mengerjakan soal IPA melalui aplikasi telegram terasa lebih menyenangkan, sebab siswa merasa antusias dengan sesuatu yang baru berupa pembelaajaran yang memanfaatkan teknologi, terjadi interaksi antara guru dan siswa, siswa mendengarkan dan memperhatikan penjelasan guru. Jadi dapat dikatakan bahwa aktivitas siswa di siklus II dapat dikategorikan lebih mampu menggunakan apliksi telegram dan lebih baik dalam pelaksanaannya dibanding siklus I, sedangkan untuk aktifitas guru selama pembelajaran telah melaksanakan langkahlangkah pembelajaran di siklus II lebih baik dari pada siklus I. Hal ini dapat ditunjukkan meningkatnya nilai rata-rata kelas ulangan formatif dan persentase ketuntasan belajar secara klasikal pada siklus I dan II yang semakin meningkat.

\section{E. Kesimpulan}

Berdasarkan paparan di atas, dapat disimpulkan sebagai berikut:

a. Pelaksanaan pembelajaran menggunakan aplikasi telegram (tele-edukasi) untuk latihan mengerjaan soal IPA menunjukkan peningkatan secara bertahap, yaknimengalami peningkatan pada hal-hal yang positif dan mengalami penurunan pada hal-hal yang negatif sesuai dengan angket siswa yang terdapat pada lampiran. Berarti dapat disimpulkan dalam pelaksanaannya berjalan dengan lebih baik dan lancar pada setiap siklusnya.

b. Hasil belajar IPA melalui penggunaan aplikasi telegram (tele-edukasi) dari pra siklus sampai dengan siklus II juga mengalami peningkatan secara bertahap. Perolehan nilai rata-rata pra siklus 61,89 dengan persentase ketuntasan belajar sebesar 21,05\%, dari 19 siswa yang tuntas hanya 4 siswa dan 15 siswa tidak tuntas.Pada siklus I rata-rata nilai 76,08 dengan persentase ketuntasan belajar 84,21\% yang tuntas 16 siswa dan 3 siswa tidak tuntas. Sedangkan pada siklus II rata-rata nilai 89,73 dengan persentase ketuntasan belajar 94,73\% dengan rincian siswa yang tuntas sebanyak 18 dan 1 siswa yang tidak tuntas. Berdasarkan hipotesis dalam penelitian ini membuktikan bahwa pemakaian aplikasi telegram (tele-edukasi) dalam latihan mengerjakan soal IPA dapat meningkatkan hasil belajar siswa. 


\section{REFERENSI}

Abdulhak, Ishak dan Darmawan, Dani. 2015. Teknologi Pendidikan. Bandung: PT. Remaja Rosdakarya Offset

Arikunto, Suharsimi. 2007. Dasar-dasar Evaluasi Pendidikan, Jakarta: Bumi Aksara

Dimyad dan Mudjiono. 2006. Belajar dan pembelajaran. Jakarta: Rineka Cipta

Munir. 2008. Kurikulum Berbasis Teknologi Informasi Dan Komunikasi. Bandung: Alfabeta

Nursalam dan Efendi Ferry. 2008. Pendidikan dalam Keperawataan. Jakarta: Salemba Medika.

Suprihatiningrum, Jamil. 2013. Strategi Pembelajaran. Jogjakarta: Ar-ruzz Media

Sudjana, Nana. 2013. Media Pengajaran. Bandung: Sinar Baru Algensindo.

Sugihartono, dkk. 2007. Psikologi Pendidikan. Yogyakarta: UNY Press

Sudjana, Nana. 2009. Penilaian Hasil Proses Belajar Mengajar. Bandung: PT. Remaja Rosdakarya.

Sanjaya, Wina. 2009. Penelitian Tindakan Kelas. Jakarta: Kencana

Trianto. 2012. Model Pembelajaran Terpadu. Jakarta: PT. Bumi Aksara

Uno, Hamzah B. 2006. Perencanaan Pembelajaran. Jakarta: Bumi Aksara

Usman, Fathor Rahman. 2013. Panduan Statistika Pendidikan. Jogjakarta: Diva Press

(http://id.wikipedia.org/wiki/Telegram_\%28aplikasi\%29)(online)

(http://www.centerklik.com/apa-aplikasi-telegram-cara-menggunakan-telegram/) (online) 